
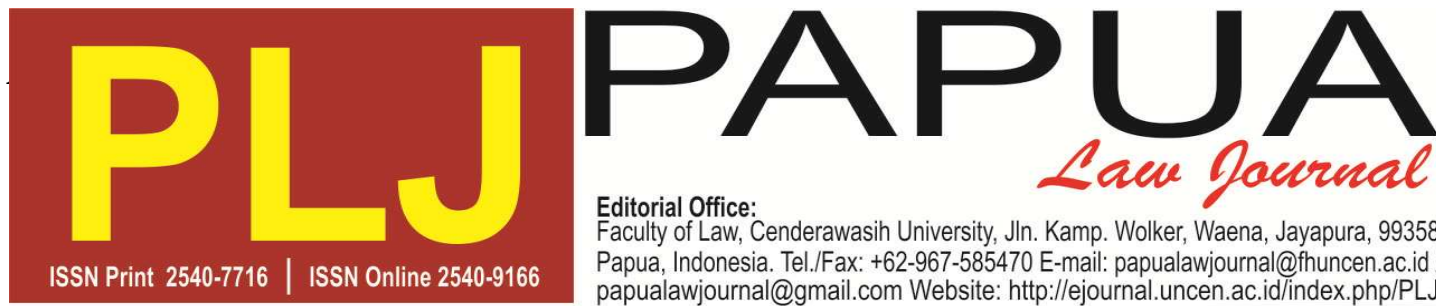

Faculty of Law, Cenderawasih University, Jln. Kamp. Wolker, Waena, Jayapura, 99358, Papua, Indonesia. Tel./Fax:+62-967-585470 E-mail: papualawjournal@fhuncen.ac.id / papualawjournal@gmail.com Website: http://ejournal.uncen.ac.id/index.php/PLJ

\title{
Public Services in Health Through Hospitals
}

\author{
Tri Yanuaria ${ }^{1}$, Kadir Katjong ${ }^{2}$

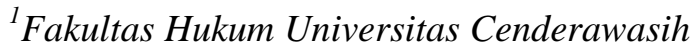 \\ JL. Kamp. Wolker, Waena, Jayapura, 99358, Papua, Indonesia \\ E-mail: yanuariatri@yahoo.com.au \\ ${ }^{2}$ Fakultas Hukum Universitas Cenderawasih \\ JL. Kamp. Wolker, waena, Jayapura, 99358, Papua, Indonesia \\ E-mail: kadirkatjong15@gmail.com
}

DOI: $10.31957 / p l j . v 3 i 2.789$

\begin{abstract}
Public service as mandated in the Law of the Republic of Indonesia Number 25 of 2009 concerning Public Services confirmed that public service is an activity or series of activities in order to fulfill service needs in accordance with laws and regulations for every citizen and resident on goods, services and/or administrative services provided by public service providers. Specifically, public services in the field of health, among others, stated that the authority of regions and cities is to administer minimum standards of health services, administer social health insurance, administer health service financing, conduct accreditation of health facilities and infrastructure and administer public health insurance systems. In its implementation there is still a Hospital in this case it can be considered that public services in health sectors have not been conducted properly or optimally because of its limitations, and therefore they have not been in accordance with the mandate of Law Number 25 of 2009 concerning Public Services and Health Laws and the Hospital Law, where there are still ethical and legal violations in conducting services.
\end{abstract}

Keywords: Public Services; Health; Hospital

\section{INTRODUCTION}

The mandate of the 1945

Constitution of the Republic of Indonesia implies that the state shall serve every citizen and population to fulfill their basic rights and needs within the framework of public services. In order to build public trust in public services carried out by public service providers, activities shall be carried out in line with the expectations and demands of all citizens and residents about improving public services.

Public services as mandated in the Law of the Republic of Indonesia Number 25 of 2009 concerning Public Services stated that public services are 
activities or series of activities in order to fulfill service needs in accordance with the laws and regulations for every citizen and resident on goods, services and/or administrative services provided by public service providers.

Bureaucratic reform is a main agenda in the current egalitarian era which increasingly emphasizes that Indonesia is a legal state (rechtstaat) which mandates that all joints of the life of the nation and state must be based on legal provisions, not on the basis of mere power (machtsaat). ${ }^{1}$ The facts reveal that the phenomenon of public services in Indonesia tends to be less well-known. Bevaola Kusumasari, ${ }^{2}$ said that the facts demonstrate that public services in Indonesia have not shown effective performance often discussed in various writings and research. This ineffective public service is triggered by a variety of complex things, ranging from bureaucratic culture that is still paternalistic, work environment that is

\footnotetext{
1 Yusdar, Irwansyah (2016) Rekonstruksi Hukum Lelang Jabatan Struktural Dalam Rangka Reformasi Birokrasi. Papua Law Journal. Vol.1 Issue 1, November. p. 103

2 Bevaola Kusumasari. (2005). Kontrak Pelayanan Dalam Revormasi Pelayanan Publik, Yogyakarta, Penerbit Gava Media. p. 87
}

not conducive to changing times, low reward system in bureaucracy in Indonesia, weak punishment mechanism for bureaucratic apparatus, low ability of bureaucratic apparatus to carry out discretionary actions, as well as scarcity of commitments by regional leaders to create responsive, accountable and transparent public services. In the era of regional autonomy which gives freedom for each region or city to run the government on the basis of its own needs and interests, it turns out that it has not been able to realize effective public services.

There are three major matters in public service, magnitude of discrimination in service, lack of service certainty, and low level of community satisfaction with public services. ${ }^{3}$ Service discrimination often arises because perceptions about the rights and obligations between service providers and service users have not reached a meeting point. Service uncertainty can be seen from two things, namely the uncertainty of time and service costs. The uncertainty of time and service costs has been

\footnotetext{
${ }^{3}$ Ibid., p. 87
} 
considered as something natural when dealing with the Indonesian public service bureaucracy. Various cases that often arise and are found imply that the community of service users is not satisfied with the services provided by the government.

In particular, public services in the health sector, according to the Circular of the Minister of Home Affairs and Regional Autonomy, among others stated that the authority of regions and cities is to administer minimum standards of health services, administer social health guarantees, administer health service financing, conduct accreditation of health facilities and infrastructure and the implementation of a public health care guarantee system. ${ }^{4}$

Even so, in practice there are often various obstacles in public service in a number of hospitals, such as the problem concerning health services to the community, especially to people who are classified as less or poor society. Hospitals in general argue with various reasons to provide health

\footnotetext{
${ }^{4}$ Surat Edaran Menteri Dalam Negeri dan Otonomi Daerah Nomor 118/1500/Pumda
}

services to the poor. On the one hand, this is contrary to one of the objectives of the public service law, such as the realization of legal protection and certainty for the public in the implementation of public services, on the other hand, however, it is contrary to the Health Law, Hospital Law and Medical Practice Law.

\section{METHOD}

The current study is kind of normative juridical research, research relating to legal norms associated with public services for the public in the health sector, then the existing data obtained, compiled, evaluated, discussed in order to obtain recommendations. The legal material used to look for data that supports this research is to collect legal material from laws, books, journals and dictionaries and other library sources related to the object of research.

\section{DISCUSSION}

The Constitution of the Republic of Indonesia in Article $28 \mathrm{H}$ stated that every person has the right to live in prosperity physically and spiritually, to live, and to get a good and healthy 
environment and the right to receive health services.

In fact, the society, especially those we face, both as personal experiences and those published through print and electronic media, in practice there are various problems related to public services in the health sector through hospitals, especially in communities that are classified as poor, because the healthcare centers have not provided optimal health services especially for free.

As the result, the impact on economically disadvantaged communities is increasingly out of reach of hopes of obtaining public services in the health sector, a common problem faced by the community is that the costs of medical treatment and care are increasingly unaffordable. Even if they get health services, they are often faced with unsatisfactory treatment such as being slow to handle in the Emergency Unit, or being detained to pay the cost of care or treatment and some are refused before obtaining health services. Such obvious situation will seriously endanger public health in the future as a result of public services that are not in accordance with the provisions of the expected rules

Public Policies and Services

Public Policies

Public policy is decision binding on many people in strategic or outline accounts made by public authorities. As the principled guide to action taken by the administrative executive branches of the state, the public policy shall be designed by political authorities, such as those who receive mandates from the public or many citizens, generally through an election process to act on behalf of the masses. Furthermore, public policy will be carried out by the state administration run by the government bureaucracy. The main focus of public policy in modern countries is public services, which are all forms of services, both in the form of goods and public services which in principle are the responsibility and implemented by the state to maintain or improve the quality of life of many human beings. ${ }^{5}$

\footnotetext{
5 Edi Suharto, Penerapan Kebijakan Pelayanan Publik Bagi Masyarakat Dengan Kebutuhan Khusus, Makalah Disampaikan pada Focused Group Discussion (FGD) "Kajian Penerapan Pelayanan Khusus (Service
} 
In its implementation, this public policy shall be derived in a series of implementation instructions and technical instructions that apply internally in the bureaucracy. Whereas from the community side, what is important is the existence of a public service standard, which describes to the community what services are their rights, who can get them, what are the requirements, also what forms of services.

To establish such desire and to design the effective policy, there shall be three necessarily noted things as follows:

a. The existence of legal instruments in the form of laws and regulations hence the public can figure out what has been decided;

b. This policy shall be clear on the implementing structure and financing; and

c. The existence of public control, a mechanism that allows the public to know whether this policy in its implementation experiences irregularities. ${ }^{6}$

for Customers with Special Needs) pada Sektor Pelayanan Publik, Lembaga Administrasi Negara, Sahira Butik Hotel, Bogor 9-10 Oktober 2008

${ }^{6}$ Wikepedia, Pelayanan Publik. http/en.wikepedia org/wiki/public_service.
Public Services

Public service is an activity or series of activities in order to fulfill service needs in accordance with the laws and regulations for every citizen and resident for goods, services, and/or administrative services provided by public service providers. ${ }^{7}$

Public services can be interpreted as providing services (serving the needs of people or communities who have an interest in the organization in accordance with the basic rules and procedures that have been set. Service is a government action that is essentially intended for the community. It is not held to serve itself, however it is designed to serve the community and create conditions that allow each member of the community to develop their abilities and creativity to achieve common goals. Therefore the government would need to be proportionally responsible, especially in terms of public services by the public bureaucracy is one manifestation of the functions of the state apparatus as public servants as well as state servants.

\footnotetext{
${ }^{7}$ Law of the Republic of Indonesia Number 25 of 2009 concerning Public Services.
} 
Whereas public services by state health institutions are defined as all forms of public service activities carried out by government agencies at the center, in the regions and within State or Regional Business Entities in the form of service delivery both in the context of efforts for community needs and implementation of regulatory provisions in the context of legislation -invitation.

An important element in public service according to Bharata $^{8}$ is as follows:

a. Service providers, as parties that can provide certain services to consumers, either in forms of services or in the form of provision and delivery of goods or services;

b. Service recipients, those who are referred to as consumers or customers who receive various services from service providers;

c. Types of services, services that can be provided by service providers to those who need services;

d. Customer satisfaction, in providing service providers shall refer to the main purpose of service, namely customer satisfaction. This is very important because the level of satisfaction obtained by the customers is usually very

8 Atep Bharata, (2004), Dasar-Dasar Pelayanan Prima, Jakarta: Elex Media. p. 11 closely related to the quality standards of goods and or services they enjoy.

The characteristics of good public services according to Kasmir have several elements as follows: ${ }^{9}$

a. good employees,

b. good facilities and infrastructure,

c. Responsible to every customer from the beginning to the end,

d. Able to serve quickly and precisely,

e. Able to communicate,

f. Guarantee the confidentiality of each transaction,

g. Have good knowledge and abilities,

h. Trying to understand customer needs, dan

i. Able to provide trust to customers.

Organizers of public services must also fulfill by several service principles, namely: Public service providers must also fulfill several service principles, as follows ${ }^{10}$ :

a. Simplicity, public service procedures are not convoluted, easy to understand and easy to implement,

b. Clarity, this formulated principle includes technical requirements

\footnotetext{
9 Kasmir, (2006) Manejemen Perbankan, Jakarta: PT Raja Grafindo Persada. p. 34

${ }^{10}$ Ratminto and Atik Septi Winarsih, (2006)

Manejemen Pelayanan, Jakarta: Pustaka Pelajar. p.22
} 
and administrative public services, work units, and details of public service costs and payment procedures,

c. Certainty of time,

d. Accuracy, public service products are received correctly, accurately and legally,

e. Security, providing security and legal certainty,

f. Responsible,

g. Facilities and infrastructure,

h. Ease of access,

i. Discipline, courtesy and friendliness, and

j. Convenience.

Public services in Indonesia tend to have some fundamental problems. In addition to the effectiveness of organizing and public participation in service delivery is still not optimal, public services also do not have a complaints mechanism and dispute resolution properly. As a result, the quality of service products has not satisfied its users.

In addition, public services in Indonesia are also not responsive to people with special needs, including vulnerable groups, people with disabilities, the elderly, the poor, and remote indigenous communities.

\section{Health Service Terms}

With regard to health services in order to achieve the desired goals according to Azwar ${ }^{11}$ there are many conditions that must be met more or less there are eight conditions as follows:

a. Availability of Health Services, meaning quality health services if services are available in the community.

b. Fairness of Health Service, it means that quality health if the service is reasonable, in the sense that it can overcome the health problems faced.

c. Continuity of Health Service, it means that quality health services if the service is sustainable, in the sense that it is available at all times, either according to time or health service needs

d. Acceptance of Health Service, it indicates that quality health services if these health services can be received by users of health services.

e. Achievement of Health Service, it indicates that quality health services if these services can be achieved by users of these health services.

f. Affordability of Health Service, it indicates that quality health services if these servants can be reached by health service users.

${ }^{11}$ Azrul Azwar, (1996). Menuju Pelayanan Kesehatan Yang lebih Bermutu, Yayasan Penerbitan Ikatan Dokter Indonesia, p. 21 
g. Efficiency of Health Service, it indicates that quality health services if these health services can be carried out efficiently.

h. Quality of Health Services, meaning quality health services if these health services can cure patients and the actions taken are safe.

\section{Implementation of Public Services in Health Through Hospitals}

From the above problems, it shows that in relation to public services in the health sector, the implementation in general has been going well, however there are still hospitals in this case it can be considered as not doing public services in the health sector according to the mandate of Law Number 25 of 2009 about public services and health laws and hospital laws, and there are still violations of ethics and law in services, such as: slow handling in the Emergency Unit, or being held to pay for treatment or even some who are refused before obtaining health services and therefore there are still discrimination in health services.

This condition if seen carefully actually every person or known as patient has the right to health services. Likewise, in an emergency the Hospital as a place or facility of health services is mandated to provide health services for the safety of human life in this regard patients and is prohibited from rejecting patients and or asking for advances. Similarly, the doctor on duty is obliged to make emergency help to patients. This can be seen from various legal instruments as follows:

Law on Public Service

The objectives of the Public Service Act are:

a. the realization of boundaries and clear relationships regarding the rights, responsibilities, obligations, and authority of all parties related to the implementation of public services, where the provision of public services must not deviate from the laws and regulations

b. the realization of a system for the implementation of appropriate public services in accordance with the general principles of good governance and corporation.

c. fulfillment of the implementation of public services in accordance with laws and regulations; and

d. the establishment of legal protection and certainty for the community in the implementation of public services.

While the implementation of public services is based on: 
a. public interest (providing services may not prioritize personal and/or group interests); there is a guarantee of the realization of rights and obligations in the delivery of services

b. legal certainty (guarantee of the realization of rights and obligations in the delivery of services);

c. equality of rights (service delivery does not distinguish ethnicity, race, religion, class, gender, and economic status);

d. balance of rights and obligations (fulfillment of rights must be proportional to the obligations that must be carried out, both by the giver and recipient of the service);

e. professionalism (service providers must have competencies that are in accordance with the task field);

f. participatory (increasing community participation in service delivery by paying attention to the aspirations, needs and expectations of the community);

g. equality of treatment / nondiscrimination (every citizen has the right to receive fair services);

h. Openness (each service recipient can easily access and obtain information about the desired service;

i. Accountability (the process of administering services must be accountable in accordance with the provisions of the legislation

j. special treatment facilities for vulnerable groups (providing facilities to vulnerable groups so as to create justice in service);

k. punctuality; and

1. speed, ease and affordability.

Hospitals in carrying out tasks in the field of health services must also be oriented to this law so that it is not discriminatory in health services and does not violate norms or regulations. In connection with the above problems for people who cannot afford and continue to receive health services in accordance with the provisions of the public service law where there are principles of equality of rights, namely: the provision of services does not distinguish ethnicity, race, religion, class, gender and economic status; and the principle of special treatment facilities for vulnerable groups, namely: providing facilities to vulnerable groups so as to create justice in services.

Law on Health

Law Number 36 of 2009 concerning Health, in Article 4 states that: everyone has the right to health. Furthermore, in the explanation of Article 4 of the Health Law, it is explained that: The right to health referred to in Article 4 is: the right to 
obtain health services from health care facilities in order to realize the highest degree of health.

Furthermore, in Article 5 paragraph (2) states that: every person has the right to obtain safe, quality and affordable health services.

Article 32 paragraph (1) of Law Number 36 Year 2009 concerning Health states that: In an emergency, health service facilities, both public hospitals and private hospitals, shall provide health services for saving the lives of patients and preventing disability first.

Furthermore, in Article 32 paragraph (2) of the Health Law that: In an emergency, health service facilities, both public hospitals and private hospitals, are prohibited from refusing patients/or asking for advances.

Hospital by Laws

Article 2 of Law Number 44 of 2009 concerning Hospitals stated that: Hospitals are organized based on Pancasila and are based on humanitarian values, ethics and professionalism, benefits, justice, equal rights and anti-discrimination, equality, protection and patient safety, and have functions social.

Article 4 of Law Number 44 of 2009 concerning Hospitals stated that: Hospitals have mandate of providing complete personal health services. Furthermore, in the explanation of Article 4 of this Law, it is explained that individual health services is defined as any health service activities provided by health providers to maintain and improve health, prevent and cure diseases, and restore health.

Article 29 paragraph (1) states that: Every hospital shall perform:

a. Provide correct information about hospital services to the community.

b. Providing safe, quality, antidiscrimination, and effective health services by prioritizing the interests of patients in accordance with hospital service standards

c. Providing emergency services to patients according to their service capabilities.

d. Providing facilities and services for poor or poor people

e. Carry out social functions, among others, by providing facilities for poor people or poor patients, emergency services without advances, free ambulances, and services for victims of disasters and extraordinary events, or social 
ISSN Print 2540-7716, ISSN Online 2540-9166

services for humanitarian missions.

Law on Medical Practice

Law Number 29 of 2004 concerning Medical Practice in principle and purpose, Article 2 stated that: Medical practice is carried out based on Pancasila and is based on scientific values, benefits, justice, humanity, balance and protection and patient safety. Meanwhile the purpose of medical practice as mentioned in Article 3 is that: a. provide protection to patients; b. maintain and improve the quality of medical services provided by doctors or dentists.

\section{Medical Ethics Code}

In the Indonesian Medical Ethics Code (KODEKI) Article explained one of the general obligations of doctors as contained in Article 7a stated that: A doctor shall be in every medical practice, provide medical services that are competent with full technical and moral freedom, accompanied by compassion and towards human dignity.

Article 8 KODEKI stated that: In carrying out its work, a doctor shall pay attention to the interests of the community and pay attention to all aspects of comprehensive health services (promotive, preventive, curative, and rehabilitation) both physically and psycho-socially, and try to be the real educators and service the truth is.

Furthermore, regardless with emergency assistance in relation to the doctor's obligation to the patient, in the Indonesian Medical Ethics Code Article 13 stated that: every doctor shall carry out emergency assistance as a humanitarian task, except that they believe someone else is willing and able to provide it.

Implementation of health services through hospitals based on the legal provisions above, if associated with the theory stated above, then when viewed from the theory of justice in the practice of health services through hospitals there is often injustice in health services due to discrimination in health services, especially for the people who are classified as poor, or the poor are not able to access health services even though the normative rule of law through the law clearly stipulates this clearly. 
The implementation of public services in the field of health through hospitals, if seen from Friedmaann's theory of the syntax of law, where a legal system consists of three components, namely structural components, substantial components, and components of cultural or legal culture, it can be seen that: institutions with all their authority, through the Ministry of Health, with Rimah Hospital and apparatus or officers, namely doctors, nurses and administrative officers who are ready to carry out health services to the community. Whereas from the substantial component, the government has provided a set of rules governing health and health services starting from the constitution, namely the 1945 Constitution of the Republic of Indonesia, the Law on Public Services, the Law on Health, and the Law on Hospitals, all of which provide cues to conduct health services properly and equitably. From a computational culture or legal culture, it appears that citizens of all levels need good and fair health services by demonstrating people's attitudes or behavior on those expectations.

The three components of the legal system as mentioned above already exist in terms of public services in the health sector through hospitals, except that in implementation mainly from structural components, where there are still hospitals with limited facilities and infrastructure, the limitations of medical personnel are therefore through means or limited infrastructure and officers have not performed services optimally even though there is still injustice in the service or discriminatory in services, especially for the poor, for example those who are not economically capable who still have not been handled properly and not even served. This condition has also at least disrupted the operation of the legal system as a whole, because one component of the structural component in its implementation does not go according to the expectations of the law or the expectations of the community. In addition, we should acknowledge that the substance component, which is a set of public service rules and regulations relating to health, hospitals, medicine, 
has not been well socialized, because not many health workers and the general public know or understand it.

\section{Several Matters Necessarily to More Improve}

Public services in the field of health specifically through hospitals in general are still not fully satisfying the community, therefore the hospital must pay attention to the following matters:

a. Hospital managers, including health workers, both doctors and nurses, many who do not understand the legal instruments relating to public services and legal instruments relating to their duties and work, such as: Health Act, Hospital Law and Medical Practice Law, because it is often in practice violating ethics and law.

Therefore, it is necessary to socialize the legal rules to be more understood so that they can be used as guidelines in carrying out tasks and work related to public services in hospitals, so that in carrying out their duties and jobs they do not violate ethics and law.

b. Hospitals shall be subjected to more improve, not only pursue profits or be oriented economically/businessly, but must complete facilities and infrastructure as well as equipment / facilities for adequate health for service purposes that can provide satisfaction to the community and not discriminatory in serving patients.

c. Internal supervision within the hospital by the head of the hospital must be carried out maximally, so that officers who work well should be given an award, and officers who do not work properly are sanctioned.

d. The government in this case the Ministry of Health shall be subjected to carry out more continuous supervision and control function for all hospitals and impose strict sanctions on hospitals that violate the law.

\section{CONCLUSION}

By way of conclusion, the description of the above obvious cases and legal instruments demonstrated that the Hospital through its managers and officers in this case, there are still a few doctors and nurses who do not understand legal instruments regarding 
Papua Law Journal. Volume 3 Issue 2, May 2019: 134-147

public services and legal instruments related to their duties and jobs thus in practice they do not conduct pleasant public services and even they violate ethics and laws relating to their field of duty.

With regard to this issue, It is time for hospitals to necessarily more improve by not prioritizing mere business orientation, in contrast, they shall be subjected to increase staffs through understanding legal instruments, good supervision and improvement of Human Resources, infrastructure, health facilities for the purpose of public services so that they can provide satisfaction to the community in the absence service discrimination and uncertainty in health services, and far from violating ethics and law.

\section{BIBLIOGRAPHY}

Azwar, Azrul. (1996). Мепијu Pelayanan Kesehatan Yang lebih Bermutu, Yayasan Penerbitan Ikatan Dokter Indonesia.

Bharata, Atep. (2004), Dasar-Dasar Pelayanan Prima, Jakarta: Elex Media. p. 11
Kasmir, (2006) Manejemen Perbankan, Jakarta: PT Raja Grafindo Persada.

Kusumasari, Bevaola. (2005). Kontrak Pelayanan Dalam Revormasi Pelayanan Publik, Yogyakarta, Penerbit Gava Media.

Ratminto and Atik Septi Winarsih, (2006) Manejemen Pelayanan, Jakarta: Pustaka Pelajar.

Suharto, Edi. Penerapan Kebijakan Pelayanan Publik Bagi Masyarakat Dengan Kebutuhan Khusus, Makalah Disampaikan pada Focused Group Discussion (FGD) "Kajian Penerapan Pelayanan Khusus (Service for Customers with Special Needs) pada Sektor Pelayanan Publik, Lembaga Administrasi Negara, Sahira Butik Hotel, Bogor 9 - 10 Oktober 2008

Surat Edaran Menteri Dalam Negeri dan Otonomi Daerah Nomor 118/1500/Pumda

Yusdar, Irwansyah (2016) Rekonstruksi Hukum Lelang Jabatan Struktural Dalam Rangka Reformasi Birokrasi. Papua Law Journal. Vol.1 Issue 1, November.

Law of the Republic of Indonesia Number 25 of 2009 concerning Public Services.

Wikepedia, Pelayanan Publik. http/en.wikepedia org/wiki/public_service. 